Попко О. В., к.е.н., доцент (Національний університет водного господарства та природокористування, м. Рівне)

\title{
СИСТЕМА НАССР ЯК ДІЄВИЙ МЕХАНІЗМ ЗАБЕЗПЕЧЕННЯ ПІДВИЩЕННЯ КОНКУРЕНТОСПРОМОЖНОСТІ ТА ПРОСУВАННЯ ВІТЧИЗНЯНОЇ ХАРЧОВОЇ ПРОДУКЦІЇ НА МІЖНАРОДНІ РИНКИ
}

Обґрунтовано необхідність та пріоритетні напрямки запровадження міжнародної системи управління якістю й безпечністю харчовою продукції НАССР як дієвого механізму підвищення конкурентоспроможності та просування вітчизняної харчової продукції на міжнародні ринки збуту. Розглянуто історію створення системи НАССР. Окреслено переваги від запровадження в практику вітчизняних операторів ринку базових принципів системи НАССР.

Ключові слова: НАССР, система аналізу ризиків і критичних точок контролю, виробництво продуктів харчування, потенційні ризики, базові принципи НАССР.

На сьогодні світова спільнота визнає проблеми якості й безпечності продуктів харчування пріоритетним орієнтиром для виробників та продавців в усіх розвинених соціальних державах. Разом 3 тим, неоднозначна політична й економічна ситуація в Україні, що спричинила нагальну потребу в переорієнтації вітчизняних операторів ринку з російського на міжнародні ринки збуту, вказує на необхідність змін в підходах до питань якості та безпечності вітчизняної харчової продукції. Йдеться, передусім, про необхідність досягнення такого рівня якості й безпечності продукції, що забезпечить їі конкурентоздатність як на внутрішньому, так і зовнішньому ринках.

Питання управління якістю належить до найбільш актуальних та таких, що традиційно активно досліджуються. Визнаними зарубіжними авторами фундаментальних праць у галузі економіки й управління якістює М. Бест, Е. Демінг, Дж. Джуран, Ф. Кросбі, М. Мінор, І. Муто, А. Робертсон, О. Уільямсон, А. Фейгенбаум, Дж. Харрингтон, Ш. Шінг та інші. Особливості маркетингового управління підприємствами різних галузей економіки в умовах динамічного ринкового середовища знайшли своє відображення у роботах таких представників вітчизняної школи маркетингу, як Л. Балабанової, А. Войчака, Н. Куденко, Є. Крикавського, О. Луція, М. Мальчик, А. Павленка, 
В. Пилипчука, С. Скибінського, О. Сологуб, М. Окландера, А. Старостіної, А. Федорченка та інших. Проте ряд теоретичних, методичних і практичних аспектів застосування маркетингу в системах управління якістю підприємств різних галузей економіки залишаються недостатньо вивченими. Це повною мірою стосується й особливостей запровадження в практику вітчизняних промислових підприємств міжнародних систем якості та безпечності харчової продукції. Недостатній рівень дослідження зазначених питань, їх важливість, теоретична і практична значимість визначили вибір теми та їі актуальність, а також постановку цілей і завдань наукового дослідження.

Європейський інтеграційний курс вимагає від України освоєння міжнародних норм та правил ведення господарської діяльності. Сертифікація продукції за системами менеджменту якості ISO вже стала звичною для багатьох підприємств. Проте на ринках Європи та США, окрім поняття «якості», існує поняття «безпечності». Саме воно $є$ ключовим у системі, призначеній для управління ризиками у галузі виробництва харчової продукції [4].

Система НАССР являє собою систему аналізу ризиків, небезпечних чинників і контролю критичних точок, що дозволяє гарантувати виробництво безпечної продукції [3]. Назва системи НАССР (ХАССП) $\varepsilon$ абревіатурою від заголовних букв англомовних слів Hazard Analysis and Critical Control Points, що в перекладі означає «Аналіз ризиків і контролю критичних точок» [7]. Система НАССР $є$ ключовим нормативним документом, який містить вимоги до систем управління безпечністю харчових продуктів для будь-яких операторів, які бажають працювати в рамках законодавства у сфері харчової безпеки на провідних міжнародних ринках.

Система НАССР є ефективним інструментом управління, який забезпечує більш структурований підхід до контролю ідентифікованих небезпек біологічного, хімічного чи фізичного походження порівняно з традиційними методами такими, як інспектування або контроль якості. Використання системи НАССР дає змогу перейти від контролю якості готової продукції на стадії завершення виробничого циклу до запровадження превентивних методів упродовж усього виробничого ланцюга. Відповідно до НАССР харчовий ланцюг (food chain) являє собою послідовність стадій та операцій, що включають виготовлення, оброблення, дистрибуцію, зберігання й перероблення засобів для харчування і харчових продуктів, від первинного виробництва до споживання. Тобто виробничий ланцюг розглядається як єдиний процес, протягом якого повинні бути усунуті всі чинники, що мо- 
жуть призвести до виробництва недоброякісної та небезпечної для здоров'я людини продукції [2].

Система НАССР ґрунтується на семи базових принципах, які представлено на рис. 1.

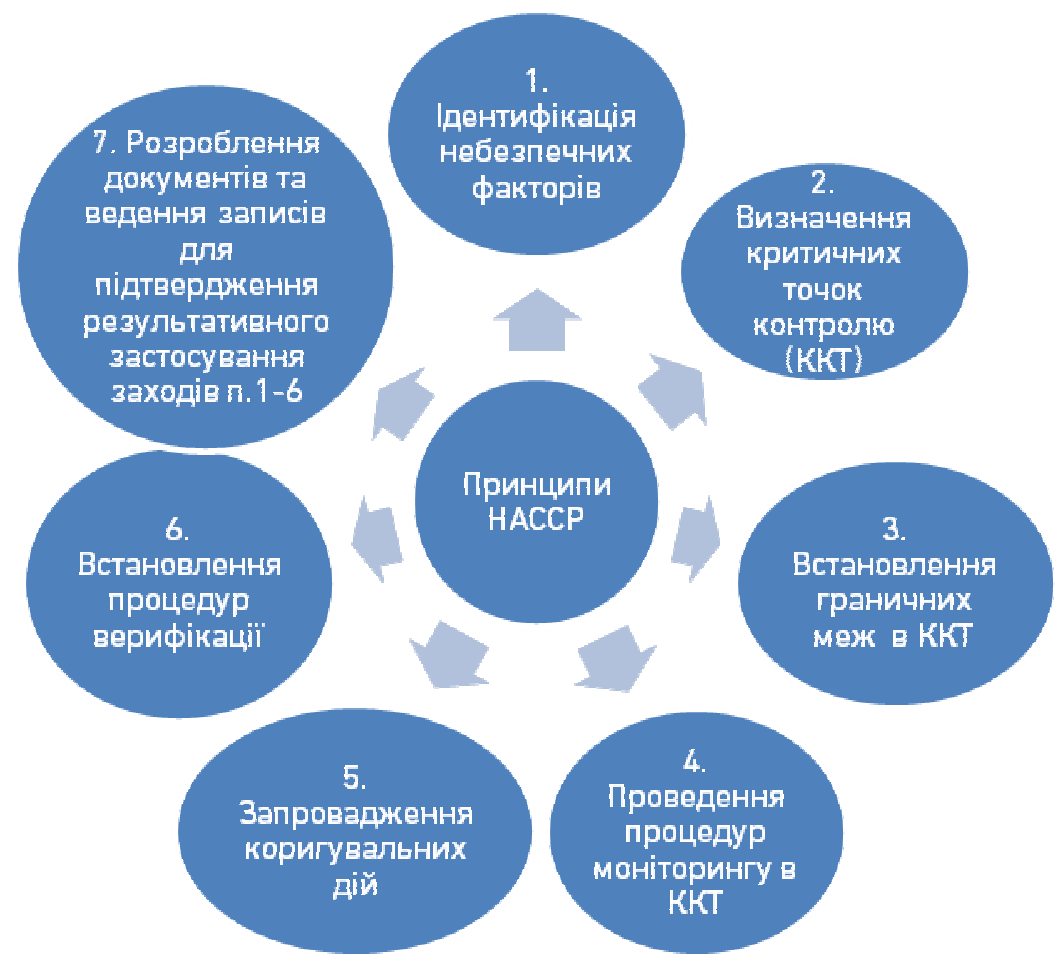

Рис. 1. Базові принципи системи НАССР

Розроблено автором на основі [8]

На основі принципів НАССР у багатьох країнах світу розроблено відповідні національні стандарти, що містять вимоги до систем безпеки харчових продуктів. В країнах Європейського Союзу, США та Канаді впровадження систем НАССР є обов'язковим для всіх підприємств харчової промисловості [4].

НАССР є основою для таких міжнародних стандартів якості та безпечності харчової продукції, як BRC - британський стандарт асоціації роздрібних торговців, IFS - міжнародний стандарт харчових продуктів, Dutch HACCP - голландський стандарт системи НАCCP, FSSC 22000:2010 - стандарт для виробників окремих категорій харчових продуктів, об'єднуючий вимоги ISO 22000:2005 та PAS 220:2008, прийнятий об'єднанням Глобальної ініціативи з безпечності харчових продуктів (GFSI) [3]. В даний час більшість торговельних мереж та великих харчових компаній пред'являють до своїх поста- 
чальників вимоги щодо наявності сертифіката відповідності системи менеджменту одному з визнаних GFSI стандартам і системам сертифікації, зокрема: McDonald's Corporation, The Coca-Cola Company, Wal-Mart Stores Inc., Kraft Foods Inc., METRO Group, Danone та ін. [2]. По суті, «замовником» стандарту системи менеджменту якості й безпечності харчової продукції, яким має відповідати виробник або постачальник вихідної сировини, виступає, споживач - конкретна торговельна мережа або компанія з виробництва харчових продуктів та інгредієнтів.

Відносно ринку Середньої Азії, то він здебільшого орієнтується на стандарти Митного союзу, згідно з якими достатньо запровадити системи управління безпекою виробництва, які відповідають принципам HACCP (ISO 22000). На Близькому Сході ситуація неоднозначна. 3 одного боку, країни, які раніше були колоніями Франції (Алжир, Туніс, Марокко), прагнуть запроваджувати у себе європейські стандарти й вимоги до безпеки та умов виробництва продукції. Товаровиробники країн Перської затоки дотримуються вимог ISO 22000 [3]. При цьому не кожен стандарт з безпеки харчової продукції дозволяє вказувати факт сертифікації у вигляді маркування на споживчій упаковці або в рекламі. Так, інформацію про сертифікацію за ДСТУ 4161 та ISO 22000 можна наносити на упаковку і використовувати в рекламі, FSSC 22000 та IFS - не можна наносити на упаковку або використовувати в рекламних цілях, BRC не можна наносити, але можна використовувати в рекламі [3].

Концепцію НАССР було розроблено ще в 60-х роках спільними зусиллями компанії Піллсбері (The Pillsburry Company) - лабораторії збройних сил США та Національного управління з аеронавтики і космонавтики (NASA). Під час роботи над американською космічною програмою NASA поставило завдання розробити систему, що гарантує безпечність харчових продуктів, які споживають астронавти в космосі з «нульовою дефектністю».

Офіційно про концепцію НАССР було заявлено в 1971 р. на Першій Американській національній конференції по захисту харчових продуктів. У середині 80-х років Національна академія наук США запропонувала здійснити адаптацію системи безпечності харчових продуктів до ринків В2С. Остаточний варіант системи було схвалено Президентом США у 1996 р. та рекомендовано для широкого впровадження спочатку на м'ясопереробних підприємствах, а згодом - на всіх без винятку підприємствах харчової промисловості [3]. Ще у 
1993 р. Комісія Кодекс Аліментаріус схвалила керівні вказівки щодо системи НАССР.

32005 року на основі базових принципів НАССР Міжнародною організацією по стандартизації (ISO) було прийнято міжнародний стандарт ISO 22000:2005 «Системи управління безпечністю харчових продуктів. Вимоги до будь-яких організацій харчового ланцюга» [3]. 31 січня 2006 року система НАССР стала обов'язковою до запровадження країнами ЄС. Стандарт ISO 22000:2005 поєднує принципи аналізу ризиків у контрольних критичних точках і практичні рекомендації, представлені в Кодексі Аліментаріус щодо гігієни продуктів харчування. Визначення небезпек, що ґрунтується на аналізі ризиків, $є$ ключовим для створення та функціонування ефективної системи управління безпечністю харчових продуктів, оскільки їх ідентифікація допомагає систематизувати знання, необхідні для створення ефективної комбінації заходів контролю. Стандарт вимагає ідентифікації й оцінювання всіх ризиків, які можуть бути передбачені та мати місце в ланцюзі виробництва і споживання харчових продуктів, включаючи ризики, які можуть бути пов'язані з особливістю технологічного процесу. Для того, щоб система безпечності харчової продукції була найбільш ефективною, їі доцільно розробляти й інтегрувати в загальну управлінську діяльність підприємства. Такий підхід забезпечує максимальну вигоду для підприємства і його зацікавлених сторін.

Стандарт ISO 22000:2005 являє собою таку систему управління безпекою виробництва харчових продуктів, яка забезпечує контроль якості на всіх стадіях виробництва харчових продуктів, у будь-якому місці процесу, від виробництва і зберігання до реалізації продукції у місцях, де можуть виникати небезпечні ситуації. Вимоги Міжнародного стандарту ISO $22000 €$ прийнятними для всіх типів організацій у харчовій сфері [2]. Ключовим моментом $€$ те, що система дозволяє не лише керувати безпекою своєї продукції на всіх етапах її виробництва, а й швидше реагувати на різного роду ситуації, тим самим скорочуючи непередбачені витрати і втрати до мінімуму. Разом з тим, потребують уваги потенційні місця виникнення небезпек, де прогалини у контролі можуть бути критичними, не врахування яких негативно вплине на якість й безпеку харчових продуктів та становитиме небезпеку для здоров'я споживачів.

Таким чином, впровадження стандарту ISO 22000:2005 сприяє підвищенню довіри до харчової продукції, що призводить до збільшення кола споживачів і партнерів не лише в межах країни, а й на 
зовнішніх ринках. Однією з особливостей ISO $22000 €$ його природна сумісність зі стандартами ISO 9001 та ISO 14001. Стандарт $є$ певним доповненням і розширенням системи контролю якості, адже 9001 не спеціалізується на харчовій продукції.

32011 року НАССР стає основою міжнародного стандарту 3 якості й безпечності харчових продуктів FSSC 22000. Принципи НАССР 31 липня 2013 року було запроваджено підприємствами харчової промисловості в Республіці Білорусь, Республіці Казахстан і РФ (згідно технічного регламенту Митного союзу «Про безпеку харчової продукції», ТP ТС 021/2011) [3].

В Україні 31 липня 2003 року введено в дію стандарт ДСТУ 4161-2003 «Системи управління безпечністю харчових продуктів. Вимоги». 31 серпня 2007 року вступив в дію національний стандарт ДСТУ ISO 22000:2007 «Системи управління безпечністю харчових продуктів. Вимоги до будь-яких організацій харчового ланцюга». На підставі підпункту 2 пункту 6 ст. 20 ЗУ «Про безпечність та якість харчових продуктів» [9] особи, які займаються виробництвом або введенням в обіг харчових продуктів, повинні застосовувати систему НАССР та/або інші системи забезпечення безпечності та якості під час виробництва та обігу харчових продуктів. 301 липня 2013 року згідно Наказу Міністерства економічного розвитку №1356 від 28.11.2012 року було введено ДСТУ-Н CAC/RCP 1:2012 «Продукти харчові. Настанови щодо загальних принципів гігієни» (CAC/RCP 11969, Rev. 4-2003).

У червні 2014 року Верховна Рада України проголосувала за Проект Закону «Про внесення змін до деяких законодавчих актів України щодо харчових продуктів» № 4179а, який стосується гармонізації законодавства країни та Європейського Союзу у сфері безпеки та якості харчових продуктів. Цим законом було регламентовано створення та функціонування єдиного контролюючого органу в сфері безпеки харчової продукції, скасування дозвільних документів і процедур, відсутніх в ЄС тощо. 317 жовтня 2015 року згідно Наказу Міністерства аграрної політики та продовольства України № 429 було затверджено зміни до вимог щодо розробки, впровадження та застосування постійно діючих процедур, заснованих на принципах НAССР. До речі, першими вимагати від своїх постачальників забезпечення відповідності принципам НАССР стали крупні торговельні мережі, такі як METPO. При чому це стосувалося не лише private label, але й усієї продукції, яка поставлялась в ці торговельні мережі. Звісно, для того, щоб працювати з такими мережами, виробники почали 
перебудовувати свої виробничі потужності та впроваджувати систему менеджменту безпеки харчової продукції, засновану на принципах НACCP.

3 набуттям чинності у вересні 2016 р. розділу VII Закону України «Про основні принципи та вимоги до безпечності та якості харчових продуктів» [8] для вітчизняних операторів ринку було встановлено терміни запровадження системи НАССР у три етапи.

Так, до 20 вересня 2017 р. вимоги щодо впровадження системи НАССР вже виконали підприємства з високим ступенем ризику, чия продукція містить активні компоненти тваринного походження, зокрема, виробники свинини, яловичини, курятини, молока як сировини. До них відносяться бійні, молокозаводи та підприємства з переробки й виробництва м'яса, тобто підприємства, на потужностях яких провадять діяльність із харчовими продуктами, у складі яких $\epsilon$ необроблені інгредієнти тваринного походження (необроблене молоко, м'ясо, риба, молюски і ракоподібні, зокрема свіжі, охолоджені або заморожені, яйця, мед, їхні похідні та інші продукти, виготовлені з частин тварин, окремих їхніх органів та/або тканин, призначені для споживання людиною. По суті, йдеться про сировину [4]. До 20 вересня 2018 р. таку процедуру мають пройти підприємства, котрі провадять діяльність із харчовими продуктами, у складі яких відсутні необроблені інгредієнти тваринного походження (кондитерські фабрики, підприємства з переробки й виробництва фруктової та овочевої продукції). По суті, мова йде про готову продукцію. Загалом, перші два етапи стосуються передусім крупних підприємств. Та вже до 1 січня 2019 р. систему НАССР мають запровадити й на малих потужностях. У цілому, широке застосування у вітчизняній практиці системи НАССР в Україні зумовлено рядом безперечних як внутрішніх, так і зовнішніх переваг (рис. 2).

Висновки. У цілому запровадження у практику вітчизняних підприємств харчової промисловості системи НАССР дасть можливість підвищити конкурентоспроможність українських виробників та посилити діючі системи управління безпекою харчової продукції. Це стане перепусткою для вітчизняних експортерів на міжнародний ринок торгівлі, зокрема до країн-членів $Є C$, а найголовніше - забезпечить внутрішній ринок високоякісною харчовою продукцією. 
Внутрішні переваги від

запровадження НАССР

системний підхід, що забезпечує параметри безпеки харчової продукціі на всіх етапах ЖЦТ - від одержання сировини до спожи-вання продукції кінцевим споживачем;

уможливлення запровадження превентивних мір;

відповідальність за безпеку харчової продукції;

визначення критичних процесів і концентрація на їх основі ресурсів та зусиль підприємства;

економія за рахунок зниження рівня браку в загальному обсязі виробництва;

\section{документальне свідчення безпеки} вироблених продуктів, що $є$ важливим при аналізі претензій і в судових розглядах;

можливості гармонійної інтеграції із системою менеджменту якості ISO
Зовнішні переваги від

запровадження НАССР можливість виходу на нові, у т.ч. міжнародні ринки збуту;

\section{зростання}

конкурентоспроможності харчової продукції на міжнародних ринках збуту;

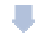

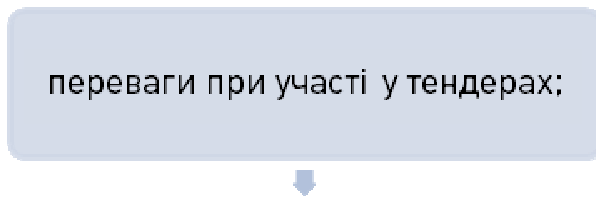

підвищення довіри споживачів до харчової продукції;

зростання інвестиційної привабливості галузі;

зниження числа рекламацій за рахунок забезпечення високої якості продукції;

створення репутації виробника якісної та безпечної харчової продукції

Рис. 2. Переваги від запровадження системи НАССР вітчизняними підприємствами харчової промисловості Розроблено автором на основі [3]

1. Вінокуров Я. В Україні почали діяти нові правила контролю за якістю харчових продуктів / HROMADSKE: сайт Громадське TБ. URL: https://hromadske.ua/posts/v-ukraini-pochaly-diiaty-novi-pravyla-kontroliuza-iakistiu-kharchovykh-produktiv (дата звернення: 06.10.2018). 2. Вимоги європейських торгових мереж до національної сільськогосподарської та 
харчової продукції, що імпортуються в $E C$ URL: http://cci.dp.ua/tl_files/data/study/FER(pdf)/Vimogi\%20jevropejskix \%20torgovix\%20merezh\%20do\%20nacionalnoji\%20silskogospodarskoji\%20ta \%20xarchovoji\%20produkciji,\%20scho\%20importujetsja\%20v\%20 JeS.pdf (дата звернення: 06.10.2018). 3. Головні положення розробки i впровадження системи HACCP. URL: http://market.avianua.com/?p=4100\#error_haccp (дата звернення: 06.10.2018). 4. Державна служба України з питань безпечності харчової продукції та захисту прав споживачів: URL: http://www.consumer.gov.ua/. 5. Консультаційно-методичний центр по сертифікації в системах ISO: URL: http://iso.kiev.ua/ (дата звернення: 06.10.2018). 6. Про державний контроль за дотриманням законодавства про харчові продукти, корми, побічні продукти тваринного походження, здоров'я та благополуччя тварин : Закон України від 18.05.2017 р. № 2042-VIII / BP України. URL: http://zakon.rada.gov.ua/laws/show/2042-19 (дата звернення: 06.10.2018). 7. HACCP. Questions \& Answers / International HACCP Alliance. URL: http://www.haccpalliance.org/sub/qanda.html (дата звернення: 06.10.2018). 8. Про основні принципи та вимоги до безпечності та якості харчових продуктів: Закон України від 23.12.1997 р. № 771/97-BP / BP України. URL: http://zakon.rada.gov.ua/laws/main/771/97-\%D0\%B2\%D1\%80 (дата звернення: 06.10.2018). 9. Про безпечність та якість харчових продуктів / HВП Поінт. URL: http://nvppoint.com/uk/pro-bezpechnist-ta-yakist-harchovihproduktiv/ (дата звернення: 06.10.2018).

\section{REFERENCES :}

1. Vinokurov Ya. V Ukraini pochaly diiaty novi pravyla kontroliu za yakistiu kharchovykh produktiv / HROMADSKE: sait Hromadske TB. URL: https://hromadske.ua/posts/v-ukraini-pochaly-diiaty-novi-pravyla-kontroliuza-iakistiu-kharchovykh-produktiv (data zvernennia: 06.10.2018). 2. Vymohy yevropeiskykh torhovykh merezh do natsionalnoi silskohospodarskoi ta kharchovoi produktsii, shcho importuiutsia $v$ YeS. URL: http://cci.dp.ua/tl_files/data/study/FER(pdf)/Vimogi\%20jevropejskix \%20torgovix\%20merezh\%20do\%20nacionalnoji\%20silskogospodarskoji\%20ta \%20xarchovoji\%20produkciji,\%20scho\%20importujetsja\%20v\%20 JeS.pdf (data zvernennia: 06.10.2018). 3. Holovni polozhennia rozrobky i vprovadzhennia systemy HACCP. URL: http://market.avianua.com/?p=4100\#error_haccp (data zvernennia: 06.10.2018). 4. Derzhavna sluzhba Ukrainy z pytan bezpechnosti kharchovoi produktsii ta zakhystu prav spozhyvachiv: URL: http://www.consumer.gov.ua/ 5. Konsultatsiino-metodychnyi tsentr po sertyfikatsii v systemakh ISO: URL: http://iso.kiev.ua/ (data zvernennia: 06.10.2018). 6. Pro derzhavnyi kontrol za dotrymanniam zakonodavstva pro kharchovi produkty, kormy, pobichni produkty tvarynnoho pokhodzhennia, 
zdorovia ta blahopoluchchia tvaryn : Zakon Ukrainy vid 18.05.2017 r. № 2042-VIII / VR Ukrainy. URL: http://zakon.rada.gov.ua/laws/show/2042-19 (data zvernennia: 06.10.2018). 7. HACCP. Questions \& Answers / International HACCP Alliance. URL: http://www.haccpalliance.org/sub/qanda.html (data zvernennia: 06.10.2018). 8. Pro osnovni pryntsypy ta vymohy do bezpechnosti ta yakosti kharchovykh produktiv : Zakon Ukrainy vid 23.12.1997 r. № 771/97VR / VR Ukrainy. URL: http://zakon.rada.gov.ua/laws/main/771/97\%D0\%B2\%D1\%80 (data zvernennia: 06.10.2018). 9. Pro bezpechnist ta yakist kharchovykh produktiv / NVP Point. URL: http://nvppoint.com/uk/probezpechnist-ta-yakist-harchovih-produktiv/ (data zvernennia: 06.10.2018).

Рецензент: д.е.н., професор Мальчик М. В. (НУВГП)

Popko 0. V., Candidate of Economics (Ph.D.), Associate Professor (National University of Water and Environmental Engineering, Rivne)

HACCP SYSTEM AS AN EFFECTIVE MECHANISM FOR IMPROVING COMPETITEVENESS OF DOMESTIC FOOD PRODUCTS AND THEIR PROMOTION ON THE INTERNATIONAL MARKETS

Nowadays the global society recognizes issues of safety and quality of food products as a top priority for their manufacturers and distributors in all socially advanced countries. Unstable political and economic situation in Ukraine, which caused the urgent need for reorientation of domestic market operators from supplying Russian markets to supplying European ones, highlights how necessary are changes in their approach regarding the issues of quality and safety of domestic food products. It means that the first and foremost priority is reaching such levels of quality and safety of products, which allow them to be competitive on both domestic and international markets. HACCP (The Hazard Analysis Critical Control Point system) is a process control system that identifies where hazards might occur in the food production process and puts into place stringent actions to take to prevent hazards from occurring. By strictly monitoring and controlling each step of the process, there is less of a chance for hazards to occur. HACCP is important because it prioritizes and controls potential hazards in food production. By controlling major food risks, such as microbiological, chemical and physical contaminants, the industry can better assure consumers that its products are as safe as good science and technology allows. By 
reducing foodborne hazards, public health protection is strengthened. There are seven HACCP principles that must be followed in order to implement HACCP. Every food production process in a plant will need an individual HACCP plan that directly impacts the specifics of the product and process. For the most successful implementation of HACCP, it should be applied from farm to table - starting on the farm and ending with the individual cooking a meal. To summarize, introduction of HACCP into the practices of domestic food manufacturing industry allows to improve competitiveness of Ukrainian manufacturers and to strengthen existing safety control systems for food products. This will be a ticket for domestic exporters to international markets including EU countries.

Keywords: HACCP, The Hazard Analysis Critical Control Point system, food production, potential hazards, public health protection, seven HACCP principles.

Попко Е. В., к.э.н., доцент (Национальный университет водного хозяйства и природопользования, г. Ровно)

СИСТЕМА НАССР КАК ДЕЙСТВЕННЫЙ МЕХАНИЗМ ПО ОБЕСПЕЧЕНИЮ ПОВЫШЕНИЯ КОНКУРЕНТОСПОСОБНОСТИ И ПРОДВИЖЕНИЯ ОТЕЧЕСТВЕННОЙ ПИЩЕВОЙ ПРОДУКЦИИ НА МЕЖДУНАРОДНЫЕ РЫНКИ

Обоснована необходимость и приоритетные направления внедрения международной системы управления качеством и безопасностью пищевой продукции НАССР как действенного механизма повышения конкурентоспособности и продвижения отечественной пищевой продукции на международные рынки сбыта. Рассмотрена история создания системы

НАССР. Определены преимущества от внедрения в практику отечественных операторов рынка базовых принципов системы НАCCP. Ключевые слова: НАССР, система анализа рисков и критических точек контроля, производство продуктов питания, потенциальные риски, базовые принципы НАCCP. 